\title{
Article
}

\section{A procedural approach to ethical critique in CDA}

Fairclough, Norman and Fairclough, Isabela

Available at http://clok.uclan.ac.uk/21356/

Fairclough, Norman and Fairclough, Isabela ORCID: 0000-0001-6718-2636 (2018) A procedural approach to ethical critique in CDA. Critical Discourse Studies, 15 (2). pp. 1-17. ISSN 1740-5904

It is advisable to refer to the publisher's version if you intend to cite from the work. http://dx.doi.org/10.1080/17405904.2018.1427121

For more information about UCLan's research in this area go to

http://www.uclan.ac.uk/researchgroups/ and search for <name of research Group>.

For information about Research generally at UCLan please go to http://www.uclan.ac.uk/research/

All outputs in CLoK are protected by Intellectual Property Rights law, including Copyright law. Copyright, IPR and Moral Rights for the works on this site are retained by the individual authors and/or other copyright owners. Terms and conditions for use of this material are defined in the policies page.

\section{CLoK}

Central Lancashire online Knowledge www.clok.uclan.ac.uk

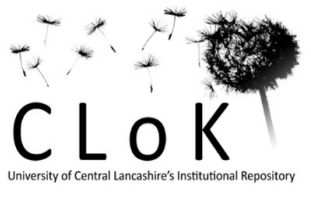


Norman Fairclough \& Isabela Fairclough

\title{
A procedural approach to ethical critique in $\mathrm{CDA}^{1}$
}

\begin{abstract}
We argue for a procedural approach to ethical critique in CDA based upon the 'argumentative turn' in CDA advocated in our recent publications. This is not a matter of abandoning substantive critique, or abandoning the long-standing commitment of our version of CDA to critique of domination and of ideology, but of integrating them into a deliberative procedure for critical questioning, from an impartial and unbiased standpoint. The advantage of this position is that it enables us to accentuate ethical criticism and critique in CDA, rather than advocacy and partisanship. The task of critical discourse analysts is to subject argumentation, including their own argumentation, to systematic critical questioning in the spirit of open debate, with no ideological parti-pris.
\end{abstract}

\section{Keywords}

Argumentative turn, critical questioning; deliberation; decision making; discourse ethics

\section{Introduction}

Critical discourse analysis (CDA) is a form of critical social analysis which focuses upon relations between discourse and other aspects of social life. Its critique is in part ethical. CDA is both normative critique and explanatory critique (Chouliaraki \& Fairclough 1999: 33, 59-69; Fairclough 2015: 10-13), and ethical critique is a part of normative critique. Not all normative critique is ethical critique. Normative critique includes critique of truth claims, in addition to critique of 'truthfulness' and 'rightness' (Habermas 1984). Ethical critique is primarily critique of actions, but actions are conditioned and constrained by social practices, institutions and structures, so ethical critique needs to be extended to them. The analytical framework we outline below can incorporate this extension.

The main concern of CDA is with political discourse, and its ethical critique is most often concerned with political values (justice, equality, liberty) as motives for action. CDA has a

\footnotetext{
${ }^{1}$ This article (accepted on 10 January 2018) is due to appear in Critical Discourse Studies, in the special issue Ethics in CDA, edited by Phil Graham.
} 
connection with politics, and an orientation towards it. Political activists can draw upon the critique of existing social realities that it provides, in formulating and advocating political policies and strategies. Moreover, as a way of engaging in critical social science, CDA has an emancipatory knowledge interest (Habermas 1986), a concern with 'wrongs' in social life, which can and ought to be put right, including political 'wrongs' (injustice, unfairness, discrimination, domination). There is a sense in which CDA is advocative - it advocates (often implicitly) action, and change to put right certain 'wrongs' in social life - and partisan - it sides with people who suffer from such 'wrongs'. But CDA is a social science method, aiming to 'speak truth to power', and that requires not being politically partisan or 'party political' in the same way that political activism is. Some work in CDA is politically partisan in this way, but our view is that it should not be. We want to argue in favour of a way of doing CDA that is not so much a form of advocacy of a particular pre-determined political standpoint, but a genuinely critical and openminded endeavour.

In taking this position, we are opting for an approach to ethical critique in CDA which gives primacy to procedural ethics, to what Habermas (1996) calls 'discourse ethics', and to a particular form of it which arises from our recent 'argumentative' approach to CDA (Fairclough \& Fairclough 2012). This involves a procedure for critical questioning of proposals for actions which can integrate considerations coming from deontological, virtue and consequentialist ethical perspectives. A procedural approach provides an ethical commitment to impartiality in CDA, which is necessary to its status as critical social science method. The procedure is applied in the normative critique of argumentation, in explanatory critique of aspects of social practices and structures, and in critique of advocated changes in practices and structures aimed at addressing such problems. Our approach treats CDA as 'dialectical reasoning', moving from normative critique, through explanation and explanatory critique, towards transformative action (Fairclough 2018).

The term 'discourse ethics' is Habermas's (Fairclough \& Fairclough 2012: 30-34), but we are using it here in a general sense: for the view that an adequate framework for ethical evaluation and critique must include the comparison and evaluation of different arguments for different lines of action in a process of deliberation. Such assessments of arguments pose difficult problems, and deliberation is by no means guaranteed to produce consensus. Nevertheless, deliberation can contribute to the quality of ethical critique by ensuring that a wide range of arguments are considered in making decisions, that all alternatives are taken into account and thoroughly criticized, and that people have to (at least) moderate their own partialities in evaluating a range of arguments collectively.

To illustrate this, we shall refer to two ethically contentious political decisions and the courses of action which they led to. The first is the decision by the British Prime Minister Tony Blair to 
advocate Britain's participation in the invasion of Iraq in 2003 (we have discussed this in Fairclough \& Fairclough 2012: 96-97). The second is the decision by the German Chancellor Angela Merkel to open Germany's borders to the refugees coming from the Middle East in the autumn of 2015. In so doing, we will illustrate the relevance of ethical critique from all three of the major ethical positions: deontological, consequentialist and virtue ethics.

\section{CDA and practical argumentation}

CDA is mainly concerned with critical analysis of discourse which is oriented to action, including political discourse, but also managerial, organisational and other forms of discourse. The primary activity in such discourse is practical argumentation, argumentation over action, over what is to be done (e.g. what policies should be adopted). Practical argumentation should accordingly be the primary analytical focus in CDA (Fairclough \& Fairclough 2012). This does not exclude other familiar forms of analysis (such as analysing representations) but subsumes them. The point of representing (or 'framing') an issue in a particular way is to create particular public attitudes and opinions, and thus legitimize or facilitate a particular course of action.

Critique of discourse is the focal concern for CDA, but critique of discourse is by no means exclusive to CDA. On the contrary, critique of discourse is a normal part of all discourse. It is a normal part of everyday practical argumentation: people find reasons in favour and against proposals for action, they consider alternatives, adopt them or discard them, and so on. A course of action worthy of being adopted is one that has withstood criticism. Agents may decide to discard proposals either because they are likely to be instrumentally inadequate in relation to the goals they are supposed to achieve, or because they find them ethically problematic, for example because the values or goals they are motivated by are unacceptable. Ethical critique is a concern for CDA at three levels: as an aspect of agents' reasoning, for example as an aspect of politicians' deliberation over what policy to adopt; as an aspect of the normative critique of those deliberative practices which CDA carries out; as an aspect of the critique that CDA itself is open to. There are therefore three main places where ethical values come into the picture: what values are arguers (e.g. politicians) arguing from? what are the values that CDA analysts are espousing, from the perspective of which they are evaluating the arguments of those arguers? what are the values of other critics (including critics of CDA)?

CDA is itself a form of discourse, which is specialized for academic critique of social actions, events, practices and structures, with a focus on discourse. It can itself be viewed as a form of practical argumentation (Fairclough 2013), open to the same critical questions that it directs at the discourse it subjects to critique. CDA practitioners are bound by an obligation to address ethical evaluations that are critical of their work. Moreover, the ethical judgement which is part of the normative critique carried out in CDA does not come out of thin air, but is built upon 
elements drawn selectively from ethical judgement and critique in public discourse. And CDA needs to rethink its own critique in response to shifts in public discourse and political reality, such as the emergence of controversy over 'political correctness' (Fairclough 2003).

We have argued that the primary focus of critical analysis in CDA should be practical argumentation and deliberation (Fairclough \& Fairclough 2012). This was based upon a claim about the character of political discourse, which we saw as primarily concerned with the question of what is to be done. Deliberation is an abstract genre in which (alternative) proposals are being tested. The framework for critical analysis of practical argumentation and deliberation which we have developed since 2012 provides CDA with an effective way of evaluating and critiquing discourse from an ethical point of view. One of its strengths is that it allows different approaches to thinking about ethical questions (deontological, consequentialist and virtue ethics) to be combined within an ethical deliberative procedure for achieving impartiality.

In a more recent version of this framework (Fairclough, I. 2016, 2018), deliberation is modelled as a critical procedure designed to filter out those practical conclusions (and corresponding decisions) that would not pass the test of critical questioning. Two distinct argument schemes are involved in deliberative activity types: an argument from goals, circumstances and meansgoal relations, and an argument from (negative or positive) consequences. Proposals are tentatively supported by practical arguments from goals, and are tested in the light of their potential consequences, via practical arguments from consequence. Goals are generated by various sources of normativity, and these can be what conventionally is called 'values', but can also be obligations, rights and duties. Critical questioning seeks to expose potential negative consequences of proposals and thus evaluate them in terms of their acceptability or reasonableness: if the consequences are on balance unacceptable for those affected, then it would be more reasonable not to engage in the proposed course of action. Unacceptable consequences are critical objections which can conclusively rebut a proposal. Where two or more proposals survive critical testing, one may be chosen as the better proposal on nonarbitrary grounds (e.g. being simpler to enact).

In our view, the most significant perspective in the light of which proposals are to be tested is a consequentialist one (Fairclough \& Fairclough 2012, Fairclough, I. 2016). The term 'consequence' is however used here broadly to refer to several types of states-of-affairs: the goals of the proposed action (the intended consequences); the potential unintended consequences (or risks) involved; various known and predictable impacts, including impacts on institutional, social facts. If a proposal is likely to result in a situation that is illegal or unjust, then the proposal can be evaluated as unacceptable from both a consequentialist ethics and a deontological ethical position. Our framework can therefore accommodate deontological 
ethical issues within a broader consequentialist perspective. By inquiring into the motives of action, the framework can also accommodate a virtue-ethical perspective.

\section{Ethics and practical argumentation - an example}

As a branch of moral philosophy, ethics is concerned with the right things to do, what ought (or ought not) to be done. There are many frameworks for, or theories of ethics - Baggini \& Fosl (2007) for instance list sixteen frameworks. Three major alternatives are widely recognized: deontological, consequentialist and virtue ethics. According to deontological ethics, people have a duty to act in certain ways and not others in accordance with moral principles and commitments. According to consequentialist ethics, people should select actions which have ethically positive consequences and reject actions which have negative consequences. According to virtue ethics, people should select actions which are virtuous and reject actions which are vicious, in accordance with virtues which they should cultivate.

Deontological ethics relates to a particular type of source of normativity: rights, duties, obligations, prohibitions, etc. These include what are traditionally thought of as values, such as political values like justice, equality and freedom (though not all 'values' are deontological constraints on action, e.g. valuing comfort or beauty). People are constrained to act in accordance with particular duties and obligations, as a consequence of the social, institutional arrangements they belong to, which provide them with 'deontic' reasons for action (Searle 2010). British Prime Ministers, for instance, should act in accordance with their obligations towards the British people, created by the commitments they undertook in becoming Prime Ministers. These include respect for and observation of the law and parliamentary democracy, the wellbeing and protection of citizens, and so on. These obligations, as sources of normativity, restrict the goals that can be reasonably pursued and the courses of action that can be legitimately chosen. The advantage of talking about 'sources of normativity' (as we first suggested in Fairclough \& Fairclough 2012), instead of merely 'values', lies in enabling us to take 'deontic' reasons into account. People have such deontic reasons for action (e.g. obligations) even when they choose not to act upon them, or are not actively concerned or motivated to act upon them. This is why their action can in fact be criticized: there is a normative expectation that they ought to act in particular ways, which sometimes people fail to fulfil.

After the publication of the Chilcot Report on Britain's role in the Iraq war of 2003, in July 2016, former Prime Minister Tony Blair defended his decision to take Britain into the war. He asked people to accept that he 'believed that it was the right thing to do' based on 'the information' that he had and 'the threat' that he perceived, and that his 'duty ... at that moment in time' was to do what he 'thought was right' (The Independent 2016). At the Labour Party Conference in 
September 2004, referring to the fact that no Weapons of Mass Destruction (WMDs) had been found in Iraq despite assertions that they existed which were used to justify the invasion, Blair had said: 'Do I know I'm right? Judgements aren't the same as facts. Instinct is not science. I'm like any other human being, as fallible and as capable of being wrong. I only know what I believe' (BBC 2004).

Blair was thus asking people to accept that he had made an 'honest mistake'. He had acted sincerely, done what he thought was right, trying to prevent greater harm. In other words, his action satisfied the demands of deontological ethics (he had done his duty), virtue ethics (he had been sincere, he had not tried to deceive and manipulate public opinion) and consequentialist ethics (his decision had been taken in order to prevent an attack on Western countries). This triple line of self-defence was not generally accepted by the British public. Acting honestly and in good faith is of course necessary for a Prime Minister, but it is not sufficient. It was also Blair's duty to make absolutely sure that the 'information' on alleged WMDs and the evidence that they posed a severe 'threat' was accurate. Blair's statement, 'I only know what I believe', suggests a bizarrely reduced view of his duties. When asked to clarify his claim, in his evidence to the Chilcot Inquiry in 2010, that it was 'beyond doubt' that Iraq was developing WMDs given intelligence reports, Blair said he 'believed' it was beyond doubt. It was pointed out to him that it was not 'beyond anyone's doubt' in 2003 that Iraq had WMDs, and that strong doubt had been expressed at the time by MPs, weapons inspectors and the media, which he ought to have considered (Hoggart 2010). There was, in other words, no support for the 'honest mistake' line of defence, either in $\mathbf{2 0 0 3}$ or later. We have suggested Blair's argument was a rationalization, a normatively defective argument where the reasons that are ostensibly offered in support of a claim are not the reasons that support the claim from the viewpoint of the arguer $-i$.e. the arguer believes the claim for other reasons. The main ethical problem with rationalizations has to do with sincerity, or honesty (a matter for virtue ethics): the arguer is being insincere, deceitful and possibly manipulative (Fairclough \& Fairclough 2012: 95-99). The decision to go to war in Iraq has also proved disastrous in terms of the long-term consequences it has generated, which the Prime Minister ought to have properly thought through.

\section{Moral-political values: one concept, several conceptions}

Justice, equality and liberty are major political values. While all three are generally acknowledged as political concepts across the political spectrum, there are different conceptions of each. In social critique, including CDA, values are however often appealed to as concepts, without much consideration of different conceptions. Failure to be precise about what conception of a value concept is being supported or opposed, and failure to make this a focus in deliberating over action, should be a concern for critique in CDA. For example, 
politicians from all sides of the political spectrum speak of fairness, justice and freedom, but they do not seem to mean the same thing when they do so. There is a danger, in CDA and elsewhere, of adopting a particular conception and talking about it as if it were the one and only one conception, for example defending equality on the assumption that a version of economic egalitarianism is the only legitimate way of talking about equality, hence if someone rejects economic egalitarianism then $\mathrm{s} / \mathrm{he}$ is rejecting equality per se.

Chapter 5 of Fairclough \& Fairclough (2012) analyzes a 2009 public debate on the fairness of bankers' bonuses and a comments thread in response to the Guardian article reporting on this debate. We distinguished there between prudential and moral arguments, the former based on interests and desires, the latter based on moral values. The prudential argument in favour of 'tolerating' bankers' bonuses took the familiar form of a 'trickle down' defence of inequality: given what is in people's interests, or given that people want prosperity for all, inequality ought to be tolerated. In the comments thread, the public generally rejected the trickle-down argument as thinly disguised 'blackmail'. Instead of this prudential view, Guardian readers put forward a variety of moral arguments against the inequality of bonuses. For example, since the state is committed to justice, and therefore obliged to act in a just manner, inequality should not be tolerated. In so doing, they drew on a broad concept of justice which they interpreted in various ways, as particular conceptions of justice.

The distinction between a concept of justice (or freedom, or equality) and particular conceptions of it is usefully made in political philosophy (Swift 2006). While the basic concept of justice (its basic grammar or logic) seems to be that it is about 'giving people what is due to them' (where this is obviously different from what people would desire to be given - punishing criminals is a way of giving them what is due to them, without being what they desire), there are various particular conceptions of justice, different ways of fleshing out the logic of the basic concept. The most influential conceptions are Rawls' (1971) conception of justice-as-fairness, Nozick's (1977) conception of justice-as-entitlement and the popular conception of justice-asdesert. Most people seem to endorse elements of all three, often in ways that, upon closer inspection, are not coherent (Swift 2006: 11-13). According to the popular conception of justice as desert, giving people what is due to them means rewarding work, talent, success. Talented and hard-working individuals deserve to get more than untalented and idle ones. Moreover, they are entitled to higher rewards for their own talents and achievements. Justice-as-fairness, associated with John Rawls (1971), says that, under a 'veil of ignorance', people would choose principles that are fair and do not privilege anyone over anyone else. Same concept of justice, different conceptions.

The comments thread illustrated all of these conceptions. Some people invoked justice-asdesert: bankers do not deserve such rewards because they are not more hard-working and talented than the rest of the population; having crashed the world economy and failed at their 
jobs, it is in fact clear that they deserve the exact opposite. Others invoked justice-as-fairness: the same treatment, the same rules should apply to all - it is not fair that banks should be rescued when they fail, and bankers too should pay the price for their recklessness, just like any other business people. Those who invoked justice-as-entitlement pointed out that bankers are only entitled to their bonuses because the bonus culture is part of a system of rules they have themselves written. These rules, while legal, are morally wrong and need changing. From these various ways of evaluating the situation from a moral point of view, various lines of action were advocated, in order to redress the perceived injustice of bonuses.

In this comments thread, readers also argued from the government's commitment to justice, from an implicit 'social contract', whose objective binding nature ought to be recognized and internalized as motivation by the government in decision making. Even when politicians fail to act from a commitment to justice, this argument goes, they ought to do so. They have a reason to do so, one that they have themselves created by accepting a mandate of political representation. Recognizing the specificity of the social world as a world of man-made institutions (commitments, contracts, laws, norms), generating external, deontic reasons (e.g. rights and obligations) that agents are bound by even when they choose to act otherwise, underlies in fact the very possibility of normative critique. What agents say and do can only be criticized by reference to what they ought to have said and done. The specificity of moral reasoning (including moral-political argumentation) derives from the recognition of such external, desire-independent reasons for action as fundamental to reasonable argumentation and decision-making. In deliberating over what to do, and in critically questioning proposals and decisions, agents are expected to give due weight to the overriding force of such reasons.

\section{Consequences or moral principles and virtues?}

Let us turn to German Chancellor Angela Merkel's decision in the autumn of 2015 to open the borders of Germany to refugees coming from the war-torn countries of the Middle East. Her reasons for doing so are a matter of controversy. A wide variety of reasons have been suggested, including: using the refugee crisis as an opportunity to admit a labour force which would benefit the German economy; wanting to improve Germany's international reputation by seeming to respond in a humane way to the crisis; wanting to out-manoeuvre the German left; being blackmailed into admitting refugees by foreign powers, the Americans or the Russians (Deliso 2017). There is also a theory that Merkel was emotionally shaken by being violently abused when she visited a refugee centre, and wanted to demonstrate her liberal credentials. Merkel's words, on August 31, 2015 - 'Wir können das schaffen, und wir schaffen das' ('We can do it, and we're going to') - may seem banal, but they had a strong resonance, evoking the ability of Germans to cope with difficult problems and their strong commitment to 
doing the right thing. On September 15, she said: 'If we now start having to apologize for showing a friendly face in emergency situations, then this is no longer my country' (Nelles 2015). As a consequence, in 2015 Germany recorded its largest influx of migrants (over one million net, and nearly 2 million in total), though only a proportion of these were from Syria (Sanders 2016).

Angela Merkel's decision continues to be highly controversial in Germany. She was widely criticized, not least by the leader of the Bavarian CSU, the sister party to the CDU (Merkel's party). Politicians and members of the public alike criticized her particularly for having made a decision on (what appeared to be) humanitarian grounds without properly considering the (immediate and long-term) consequences of such a large influx of immigrants. Merkel's decision, whatever its motives, and its critical evaluation are an excellent illustration of the three ethical frameworks at work, and the way in which they all make overriding demands on decision-makers. Which kind of ethics should be given primacy? Should she neglect humanitarian and categorical moral imperatives, i.e. the demands of virtue (charity and compassion) and deontological ethics (moral duty and obligations under international law), and keep borders closed in order to avoid negative impacts on the German and other European nations? Or should she, on the contrary, act from a sense of overriding duty, or overriding charity, and ignore the risks and impacts?

A January 2016 article entitled 'The Isolated Chancellor. What Is Driving Angela Merkel?' in Der Spiegel (Feldenkircher and Pfister 2016) puts her dilemma into sharp perspective. Speculating on the motives of her decision, the authors begin with an anecdote. At a charitable concert for the refugee cause, Angela Merkel was told by a friend, a man of the church, that her 'courageous and wonderful' refugee policies reminded him of the words of former Czech president and dissident Vaclav Havel: 'Hope is not the conviction that something will turn out well, but the certainty that something makes sense, regardless of how it turns out'. These words had apparently made a strong impression on the Chancellor. The article continues in this way:

It is completely unclear how the experiment will end that the German chancellor has forced upon the European Continent, upon her fellow citizens and, not least, upon her party. Her decision late last summer to open the German border to refugees transformed Merkel into a historic figure. It was the most consequential decision of her entire decade in office. The US newsmagazine Time named her Person of the Year, and in the fall she was widely considered to be in the running for the Nobel Peace Prize.

Since then, the mood has shifted, and not just in Germany. To prevent 'a rebirth of 1930sstyle political violence', New York Times columnist Ross Douthat recently wrote, 'Angela 
Merkel must go' (...). As much as the decision to open the borders itself, what amazes many observers is the stubbornness with which Merkel has maintained her political course. Neither the terror attacks in Paris nor the sexual assaults on New Year's Eve in Cologne - neither the indignation of furious German citizens nor the warnings from within her own party - have led Merkel to question her decision to keep Germany's borders open. It seems as though Angela Merkel - à la Vaclav Havel - is convinced that her course of action makes sense. No matter how the situation turns out.

... Half the world is wondering what is motivating the German chancellor. What's the answer? What's driving Angela Merkel, a woman who gained power by virtue of her implacable pragmatism and who is now governing so unconditionally? Why has she thus far shown no serious indication that she might shift course on refugee policy despite the fact that her popularity ratings are plummeting and the foundations of her power are crumbling?

Merkel's chief of staff, Peter Altmaier ... is the voice of Merkel's refugee policy... From Merkel's perspective, Altmaier explains, this is what the world looks like: in order to avoid a humanitarian catastrophe late last summer, she had little choice but to open the borders. Now, the task is that of preventing Europe from falling apart. Were Germany to now close its borders, it wouldn't just mark a failure for Europe's border-free travel regime known as Schengen. The refugee flow would also backup across the Balkans and would destabilize the fragile young democracies there... Greece would become overrun with desperate refugees from Syria and Iraq while Jordan and Lebanon, which are already hosting almost 2 million refugees, could be pushed to the brink of collapse.... That, at least, is the official version. When speaking with Merkel's people, her refugee policies come across as being entirely rational. Like a chain of political necessities. (...)

On July 15, Merkel met a 13-year-old girl named Reem Sahwil at a town meeting in the northern German city of Rostock. The girl had fled to Germany from Lebanon four years before but she was now in danger of being deported. 'It is really painful to see others really enjoying life when you can't enjoy life yourself,' the girl said. It was the old Merkel who answered. She didn't want to seem heartless, but she also didn't want to make any promises just because she had stumbled into an awkward situation. '(If we would say) you can all come from Africa, and you can all come - we couldn't handle that,' Merkel stammered. Couldn't handle it. Not long after Merkel finished, Reem began crying and Merkel awkwardly tried to comfort her. In the days that followed, Merkel was accused of being cold-hearted and she was widely criticized on the Internet. (...) 
In the days that followed, something changed in the Chancellery. When Merkel gave her annual summer press conference on August 31, she no longer said that Germany is unable to take everybody. Neither did she speak of the risk of being overwhelmed, like she had in Rostock. 'Germany is a strong country,' Merkel said. 'The motivation with which we should approach these things has to be: We have handled so much. We can handle it!' (...) On Sept. 4, she opened up the border to the refugees trapped in Hungary. Later, she said that she had watched on television as people from Syria had gathered in the Keleti train station in Budapest and were then prevented from continuing their journey. She found it outrageous. Merkel decided to allow the refugees to come to Germany. Three days later, she said she was 'a bit proud of our country.'

From then on, the numbers of refugees coming to Germany began to climb rapidly. Soon, it was 10,000 per day - and as the influx grew, so too did the number of Merkel's critics. Bavarian Governor Seehofer said that Merkel had made a mistake that would affect Germany for a long time to come...(...) The Germans may wish for a time prior to the refugee crisis, but that is a wish she cannot fulfill, Merkel said. Of course, she could close the borders, but then masses of people would accumulate in front of the barbed wire. The images would be ugly. Germans, she said, can't even stand it when someone is forced to spend the night outside.

She, though, wanted to combat the causes of the refugee crisis at the roots and cooperate with Turkey, Merkel said. As long as she was leading, Germany would not become a country that intentionally chased away people in need. 'I will not become involved in a competition for who can treat the refugees the worst,' she said. (...) Merkel, of course, also saw the refugee crisis in the light of realpolitik. She has long pursued the goal of stealing centrist voters away from the center-left Social Democrats (SPD). (...) Yet if it had only been about tactics, Merkel would have abandoned her approach long ago, at the latest when the right-wing populist party Alternative for Germany (AfD) began rising in the polls and her own popularity figures began dropping. There must be a different, more personal motivation, for her unwillingness to change course...

[A close friend] believes that her Christian roots are very apparent in her approach to the refugee crisis. 'She is the daughter of a socialist pastor. And her mother was an extremely devout woman. Such things are deep within you, they don't just disappear,' he says. [Her family] adhered to a practical form of theology that involved helping the poor, sick and disadvantaged.... Merkel grew up with the tenet that, if a stranger is standing in the rain before your door, you let him in and help... 
In these journalists' view, Merkel may have acted from a sense of Christian duty (or from some categorical moral imperative), overriding whatever other reasons she may have had. She may also have been driven by (the virtues of) charity and compassion, and possibly also by (personal and political) self-interest. But, at least from this account, it seems that potential consequences of her decision did not seem to carry much weight: her course of action seemed right to her, and 'made sense', regardless of the consequences, regardless of how things would 'turn out'. According to the above account, taking the consequences into account seemed at best an afterthought: Angela Merkel seemed more concerned with the consequences of reversing her original decision.

The discussion of Merkel's 'motives', of the 'normative sources' that led her to a particular conclusion and decision, continues in the comments thread attached to this article in Der Spiegel (47 comments, amounting to around 4600 words). There is no space for a detailed account here, but we will quote one of these comments, for illustration (from eugenefine, on 01/26/2016, entitled 'Merkel - Driving migration'):

A very compelling article. But utterly disingenuous. Much sentimental verbiage. No mention of Merkel's ruthless humiliation of Greece, ongoing. Passing reference to her autocratic dismissal of the concerns of her EU partners. There is nothing very [compelling] about these. On the contrary, there is a chilling dimension to the notion of the certainty that 'something makes sense, regardless of how it turns out'. Is that not a succinct encapsulation of the mindset of Fascism? Is this not the same 'logic' that informed the Final Solution? Germany should be very mindful of the dangers of absolutes and of imposing them on others. As I read the words of Rainer Eppelman, quoting Vaclav Havel, and how Merkel was so impressed with them, a cold chill passed over my body... The crisis is in real danger of giving rise to the unthinkable. Dressed up in the language of humanitarianism, is has all the ingredients of a determinism to something quite different. You are correct to identify Merkel's policy as an 'experiment', but how dangerous to undertake such a venture without more care and sensitivity, especially to the experience of our histories. What 'makes sense'? To make unilateral decisions with enormous consequences for the EU without consulting EU Members? To commit to a 'welcome' to an (as yet) unlimited number of potentially limitless numbers of migrants? To persist with this policy in defiance of public support? To create dissension between EU Members in a hideous game of shaming and isolation and threats to those of a different viewpoint? To allow traffickers and NGOs (of variable credibility) to continue to hardwire the exploitation of the migrant trail? To entertain sham engagements with Turkey and Greece? To use the obscenity of the migrant trail as a baton by which to enforce Shengen? To tar every attempt by ordinary decent people to engage in Spiegel's earlier 
reasonable appeal for 'measured debate' as being 'right wing, fascist, racist and xenophobic'? ... No doubt Angela Merkel meant well. But she is Chancellor of Germany. Naivety is a kind word in this instance....

For eugenefine, there is a 'chilling dimension' to the 'certainty that something makes sense, regardless of how it turns out' - this, s/he says, is the mindset of Fascism, 'dressed up in the language of humanitarianism'. Acting from a sense of absolute, overriding duty, without regard for consequences, can be dangerous (this being in fact a standard objection to a Kantian deontological approach). Angela Merkel, this reader argues, should have never made 'unilateral decisions with enormous consequences for the EU without consulting EU Members', nor should she encourage the 'tarring' of those ordinary people who disagree with her as 'fascist, racist and xenophobic'. At best naïve, the reader suggests, Angela Markel seems to have misunderstood her obligations as Chancellor toward her own people.

This kind of critique, along the lines that Angela Merkel has misunderstood the demands of duty, charity and justice, saying, for example, that in being charitable and compassionate (virtues), she has failed in her obligations as a politician, and been unjust to the German people, has been heard many times, in various forms since 2015 (Murray 2017: 294-296). Clearly, the deontic powers which attach to her institutional position as Chancellor include the obligation to make decisions on the basis of a proper assessment of the negative consequences that are likely to follow, and by consultation with others (we made the same argument in relation to Blair's decision), and in the light of a public democratic mandate (as an elected politician) Whether she or anyone else involved had anticipated those consequences on Germany and Europe, the criticism goes, they had not entered into her decision and action, nor had a process of democratic deliberation and consultation taken place, which are serious ethical and political failures.

We have discussed the ethics of Blair's and Merkel's decisions and actions, but what about the ethics of CDA? What should the CDA analyst do when analyzing such debates? If CDA gives primacy to 'discourse ethics' in its ethical critique, as we think it should, it is committed to applying that critique to a reasonably representative range of the proposals which figure in the debate, in an even-handed way which aims for impartiality, and to evaluating proposals according to whether they stand up to critical testing. Analysts will generally have their own views about the rights and wrongs of such decisions and actions, but they should not allow their own political agendas to shape their critical analysis. They should not short-circuit the deliberative procedure for ethical evaluation and critique by rejecting standpoints different from their own out of hand, for instance by labelling them 'racist' or 'xenophobic', or in other ways unreasonable, without considering those standpoints impartially, on their merits, based 
on factual evidence. Many CDA analysts are also political activists, and in many cases it is their political convictions that have attracted them to CDA. This can lead to tensions between the demands of politics and the demands of critique, but the value and credibility of CDA depends upon analysts keeping them apart.

\section{CDA as argumentation and critique}

CDA is a form of explanatory critique as well as normative critique. Explanatory critique explains problems (identified through normative critique) as effects of existing states of affairs, including social structures and practices. Aspects of existing states of affairs which lead to such problems are themselves taken to be part of the 'problem', and consequently need to be changed in order to resolve the 'problem'. This allows our framework to extend critique, including ethical critique, from actions and events to practices, institutions and structures. Explanatory critique incorporates a move from facts to values: $x$ causes problem y (fact), so $x$ is a 'wrong' that needs righting (value). In committing itself to explanatory critique, CDA moves from the question of what is problematic or flawed in existing states of affairs towards the question of what should be done, and from a concern with ethical problems towards a concern with ethical solutions.

This is the move that is made in practical argumentation: from problematic existing circumstances to goals and actions to change them, all in the light of values (as normative sources). CDA itself can be thus seen as a form of practical argumentation. We have suggested that it is a form of practical argumentation which we have called 'dialectical reasoning' (Fairclough 2018), with the following four steps:

1. Normative critique of discourse.

2. Explanation of normatively criticised discourse in terms of features of the existing state of affairs (existing social reality).

3. Explanatory critique of the existing state of affairs.

4. Advocating action to change the existing state of affairs 'for the better'.

Practical argumentation often has a problem-solution structure, moving from the identification of problems in existing circumstances - the 'problematization' of existing circumstances - to proposing solutions to these problems, in the light of external deontic constraints. For example, in proposing a solution (doing $A$ ) in order to resolve a problematic situation, agents will have to make sure that $A$ does not clash with their obligations to respect institutional arrangements already in place (i.e. whatever proposal is adopted, it will have to be legal, moral, etc.).

It has long been recognized that, while CDA has generally focused upon 'negative' critique of existing states of affairs, its critique also has a 'positive' element, even if this is left implicit in 
most analyses. For instance, in problematizing what Tony Blair said and did in the run-up to the Iraq war, one is inevitably suggesting what he should do (if the critique is contemporary with the events) or should have done. Taking CDA to be this particular form of practical argumentation, dialectical reasoning, is a way of making this move from problems to solutions explicit.

There are good grounds for the view that solutions are an inherent part of CDA: critique and problematization of existing circumstances and states of affairs are inconceivable without positing possible alternatives to what actually exists. We can see this as the application of 'sociological imagination' (Mills 1959): social critique situates its local and particular objects of critique in the wider social context of social practices and structures, which not only enables explanation of problems, but also enables identification of hitherto unrealized possibilities, what is potential in existing states of affairs as well as what is actual, what could be as well as what is. This has an ethical aspect: possible alternatives must not only provide feasible, achievable solutions to problems, they must be more than instrumentally adequate. The imagined solutions must meet ethical criteria, they must be generated by goals and values, by normative sources that can be argumentatively defended as the 'right' goals and values to have. 'Imagination' plays an essential role in practical reasoning. Solutions are imagined, on the basis of an analysis which identifies the unrealized potential in existing states of affairs, then tested in the light of their consequences: would they achieve the stated goals? would they have unacceptable side effects?, and so on. You cannot problematize what is actual without at the same time imagining possible solutions.

This gives rise to problems of differentiation and demarcation which bear upon the ethical character of CDA itself, and the ethical critique which it is open to. Politics, in the sense of political activism, is also in the business of finding solutions to problems. Is CDA politics, or is there a difference between the two? CDA often appears to be political advocacy, advocating certain political positions, strategies or policies, and actions, and directing its social (including ethical) critique of discourse at other political positions, strategies, policies and actions which are incompatible with those advocated; politically partisan, as we put it in the introduction, 'party political'. Should we accept this, or should we insist on a clear demarcation between CDA and politics?

As we noted in the introduction, there is a limited sense in which CDA is a form of advocacy and partisanship. CDA is committed to 'righting' perceived social 'wrongs', and sides with people who suffer from such 'wrongs'. There is a tension between advocacy and partisanship in CDA, on the one hand, even in these limited forms, and its commitment to social scientific critique, on the other. CDA sometimes tends to slide into political activism, and continuing debate over where the line should be drawn is inevitable. But there should be a clear difference between politics and CDA in what is focal: action to bring about social change in politics; critical analysis 
and understanding of problems, as a basis for imagining feasible and ethical solutions, in CDA. The focus in CDA needs to be on critique, on criticism, which includes a willingness to subject its own standpoints to critical questioning, rather than defending a pre-determined normative standpoint, even in the face of evidence that it may be unreasonable. (An observation which W.B. Yeats makes about poetry helps to make the point: 'will must not usurp the work of imagination'. Poetry is also sometimes concerned with the righting of 'wrongs', but the 'will' to do so must not 'usurp' its focal concern with 'the work of imagination'. And will must not usurp critique in CDA.)

In our view, CDA can best protect its focal concern with social scientific critique by giving primacy to a methodological procedure. With respect to its ethical critique, in particular, CDA should privilege a procedural 'discourse ethics', grounded in a requirement of impartiality, of evaluating diverse and conflicting proposals for action, and incorporating a multiplicity of possible ethical standpoints - deontological, consequentialist and virtue ethics. CDA itself can be seen as practical, deliberative reasoning: the analyst evaluates practical argumentation (e.g. in political discourse), and proposes possible solutions to problems, in the light of goals (as desirable 'imaginaries') and in accordance with normative sources such as moral-political values. These goals and normative sources are selected in accordance with the limited advocacy and partisanship of CDA as a form of critical social analysis.

A commitment to discourse ethics is the most important part of the ethics of doing CDA. What should distinguish CDA from political activism is a commitment to impartiality and to methodological attitude, manifested in the primacy given to the notion of criticism, e.g. the use of a systematic framework for analysis and evaluation of argumentative discourse. CDA has often selected for critique only discourse which it strongly disagrees with. A useful rule of thumb would be to also critically question argumentation which has a similar perspective to its own, or indeed its own argumentation, not in order to provide a 'balanced view', but in order to make its own claims open to critical questioning, identify and respond to possible counterarguments, and ensure that it is not biased. This is particularly important in the light of prevailing tendencies for political cultures and practices to shift towards self-confirming positions, with political groups inhabiting 'bubbles' and rejecting engagement with opponents. One way of doing this is by applying labels (e.g. 'sexist', 'racist' or 'politically correct'), which not only prevent much needed debates from taking place in society, but also discredit and even criminalize argumentative opponents. This is of course a permanent feature of politics, but there seems to be an alarming increase in scale and effect. CDA has a methodological commitment to an open and impartial process of critical questioning, in which arguments for different lines of action are evaluated and criticized. This is not designed as a model for politics, but it can nevertheless set a standard which politics, in its parlous contemporary state, might benefit from. 
Argument evaluation that contributes to ethical critique can involve questioning of the value and goal premises (are the stated values and goals acceptable?), criticizing the proposed action itself in the light of its potential consequences (if these are on balance unacceptable, then the proposal cannot be defended), and criticizing the truth of the premises (e.g. is true that the agent is motivated by the goals and values he claims to be motivated by? Is the description of the situation, or 'problem' to be resolved, accurate?). In deliberating over action, agents are often faced with competing goals, competing obligations, arising from various sources of normativity. For example, they might be expected to sacrifice their desires in order to fulfil an obligation. Or they might be expected to give up some perceived benefits in order to avoid some unacceptable costs.

This critique needs to be extended in two connected directions: adding a critique of existing institutional deontologies, and adding a wider (ethical) critique of existing social practices and structures. These are secured through our view of deliberation in CDA as a form of dialectical reasoning, and specifically though the move from normative critique of discourse to explanation, and to explanatory critique of existing states of affairs, practices and structures, and to the advocacy of action to change existing states of affairs 'for the better' which this leads to. Decisions made in accordance with all the relevant institutional rules, for example, may not be legitimate, i.e. may not withstand a process of public justification, if the institutional framework is unfair. The institutional set-up may be such as to bias decisions in accordance with the interests of certain parties or agents. For example, decisions against shale gas applications taken at local county council level can be legally reversed by government ministers on appeal (Fairclough forthcoming). In such cases, where all decision-makers have fulfilled their institutional obligations, according to the rules in place, the problem lies with the institutional design, not with the failure of agents to comply with its constraints. Normative critique needs to be supplemented by explanatory critique, by asking why the institutional arrangements are they way they are, and whose interests they serve, and how existing states of affairs need to be changed, for instance in ways which strengthen local democracy by devolving more powers to local authorities.

\section{Identity politics and political correctness}

There are two more issues with ethical implications, which are closely connected, that we would like to address: identity politics and 'political correctness' - both have been relevant to the concerns of CDA. Identity politics emerged out of new social movements in the 1960s and 1970s which focused upon inequalities and injustices affecting for instance women (e.g. there were very few women in parliament or in senior management, and those there were had to overcome obstacles which men generally did not), gay people (e.g. homosexuality was only 
decriminalized in Britain in 1967), black people (e.g. the Race Relations Act prohibiting racial discrimination in employment, housing etc was passed only in 1968). On the political left, an exclusive focus upon class inequalities and injustices was substantially shifted to include inequalities/injustices on grounds of gender, sexuality, and race. Existing institutional deontologies were criticized for excluding such inequalities and injustices, and substantively changed. But these developments have arguably led to a tendency to focus political struggles for justice and freedom too much on particular identity groups, and to a form of politics which came to be criticised as 'politically correct' (PC).

Here is a part of a left-wing critique of 'PC' by Stuart Hall (1994):

Taken together, these things go some way to explaining the particular style of PC: its confrontational, in-your-face mode of address. It consciously intrudes a stance and tone of voice which seem more appropriate to public contestation into so-called 'private space'. Many have commented on the intellectualist or 'academic' nature of PC politics. I think they not only mean that PC seems to be often contained within academia. They are also referring to what some philosophers call its extreme 'nominalism', that is to say, its apparent belief that if things are called by a different name they will cease to exist. It has a highly individualistic notion of politics - politics as the lone embattled individual 'witnessing to the Truth'. PC gives the impression of a small but dedicated band who are determined to stand up and be counted. That isn't the only sense in which PCers remind one of latter-day Puritans like the Saints of the seventeenth century. A strong strain of moral self-righteousness has often been PC's most characteristic 'voice'.

PC is of relevance to the concerns of this paper because of its 'moral self-righteousness', and the attraction of identity politics for many practitioners of CDA with, in some cases, a leaning towards PC. Given our emphasis on procedural and deliberative ethics in CDA's ethical critique, we are strongly opposed to any PC tendencies in CDA. Defenders of multicultural identity politics should perhaps reflect on how the focus on the rights of groups has tended to be at the expense of the rights and responsibilities of all citizens. In emphasizing 'community', seen as a cultural and religious entity, multicultural policies have downplayed the requirement for all identity groups, all religious communities, to adhere to a shared set of fundamental political values. They have led to segregation along ethnic or religious lines, and failed to produce a political community of citizens.

But there is also another relevant characteristic of the politics of PC: as we have said, labelling opponents as 'racist' or 'xenophobic' can have the effect of closing down political debate and discrediting or even criminalizing one's argumentative opponents. This is not only morally objectionable, but will also eventually backfire, producing undesirable consequences. Arguably, 
one of the causes of the Brexit vote in June 2016 had to do with the way a legitimate debate over migration into the UK, which many people felt was overdue, had been persistently stifled by certain (typically left-wing) political and intellectual elites branding everyone who objected to increasing migration as 'racist' and 'xenophobic'. Many legitimate arguments, driven by values and concerns that had nothing to do with racism, had been suppressed for too long, and arguably found expression in the Brexit vote.

One effect of the fragmentation of broad political constituencies, notably the 'labour movement' as a working class movement combining trade unions and left political parties, is a tendency in politics towards self-confirming political 'bubbles', on the right and on the left, in which members of a 'bubble' think about and talk to each other, but rarely outsiders. There is a difference between left and right in that, while the former tends to moral (self-)righteousness, the latter tends to mockery: 'PC' is a mocking, ironic or sarcastic term which evokes aspects of the PC style identified by Hall. Both can be seen as forms of ethical critique; but the emphasis for the left is on deontological ethics, on what is morally 'wrong', whereas the emphasis for the right is on virtue ethics, on the vices and flaws of certain categories of people. Mockery is common - a recent example involves referring to students seeking 'safe' spaces where their feelings will not be 'hurt' as 'snowflakes' - but not essential. Labelling welfare claimants as 'spongers' has a self-righteous moralistic tone. However, CDA practitioners should not only critically evaluate terms such as 'snowflakes' and 'spongers', but should also interrogate the reasonableness of the idea of 'safe spaces' in universities, and the justification of the UK's socalled 'benefits culture'.

Summing up, we think CDA should give more attention than it has done to the politics of PC and the debate around PC. We argued above that CDA's own ethical critique is built out of ethical critique in public discourse, and that it needs to rethink its own critique in response to shifts in public discourse and crucially in response to facts and evidence. PC is the clearest recent example. This does not mean uncritically adopting the critique of PC, though it does mean recognising (with Hall 1994) that there is some substance in it. Critical evaluation includes assessing whether or not there is factual justification for such labels as 'racist' or 'sponger'; for instance, as Browne (2006) puts it, whether calling people 'racist' is 'factually correct' as well as purportedly politically correct, or whether calling people 'spongers' is factually incorrect as well as purportedly politically incorrect.

\section{Conclusion}

We have argued for a procedural approach to ethical critique in CDA based upon the 'argumentative turn' in CDA advocated in our recent publications. This is not a matter of abandoning substantive critique, or abandoning the long-standing commitment of our version 
of CDA to critique of domination and of ideology, but of integrating them into a deliberative procedure for critical questioning, from an impartial and unbiased standpoint. The advantage of this position is that it enables us to accentuate ethical criticism and critique in CDA rather than advocacy and partisanship. The latter do have a place in CDA in the limited form which we have indicated, though not in the 'party political' form of political activism, but the centre of gravity in CDA should be subjecting argumentation, including its own argumentation, to systematic critical questioning in the spirit of open debate, with no ideological parti-pris.

\section{References}

Baggini, J. \& Fosl, P.S. (2007) The Ethics Toolkit. A Compendium of Ethical Concepts and Methods. London: Blackwell.

BBC (2004) Full text of Tony Blair's speech to the Labour Party conference in Brighton. 28 September. At: http://news.bbc.co.uk/1/hi/uk_politics/3697434.stm (accessed 1 October 2017).

Browne, A. (2006) The Retreat of Reason. Political correctness and the corruption of public debate in modern Britain. London: Civitas.

Chouliaraki, L. \& Fairclough, N. (1999) Discourse in Late Modernity. Edinburgh: Edinburgh University Press.

Deliso, C. (2017) Migration, Terrorism, and the Future of a Divided Europe: A Continent Transformed. Santa Barbara, California: Praeger Security International

Fairclough, I. \& Fairclough, N. (2012) Political Discourse Analysis: A Method for Advanced Students. London: Routledge.

Fairclough, I. (2016). Evaluating policy as practical argument: the public debate over the first UK Austerity Budget. Critical Discourse Studies, 13(1): 57-77. DOI:

10.1080/17405904.2015.1074595

Fairclough, I. (2018). Deliberative discourse. In J. Richardson \& J. Flowerdew (Eds.), The Routledge Handbook of Critical Discourse Analysis. London: Routledge, 242-256.

Fairclough, I. (forthcoming) Deontic power and institutional contexts: the impact of institutional design on decision-making in the UK fracking debate. Argumentation in Context.

Fairclough, N. (2003) Political correctness Discourse \& Society 14.1, 17-28.

Fairclough, N. (2013) Critical discourse analysis and critical policy studies, Critical Policy Studies 7.2, 177-197.

Fairclough, N. (2015) Language and Power $3^{\text {rd }}$ edition. London: Routledge.

Fairclough, N. (2018) CDA as dialectical reasoning, in J. Flowerdew \& J. E .Richardson eds. The Routledge Handbook of Critical Discourse Studies. London: Routledge, 13 - 25. 
Feldenkirchen, M. \& Pfister, R. (2016) The Isolated Chancellor. What Is Driving Angela Merkel? Der Spiegel, January 25, at http://www.spiegel.de/international/germany/why-has-angela-merkelstaked-her-legacy-on-the-refugees-a-1073705.html

Habermas, J. (1984) The Theory of Communicative Action, Vol. 1: Reason and the Rationalization of Society, trans. T. McCarthy. London: Heinemann.

Habermas, J. (1986) Knowledge and Human Interests. Cambridge: Polity Press.

Habermas, J. (1996) Discourse ethics, in W. Outhwaite ed. The Habermas Reader. Cambridge: Polity Press, 248-265.

Hall, S. (1994) Some 'politically incorrect' pathways through PC, in S. Dunant, ed. The War of Words: The Political Correctness Debate. London: Virago Press, 164-184.

Hoggart, S. (2010). Regrets? Oh come off it. The Guardian, at https://www.theguardian.com/politics/2010/jan/29/simon-hoggart-sketch-blair-chilcot (accessed 1 October 2017)

Mills, C. W. (1959) The Sociological Imagination. Oxford: Oxford University Press.

Murray, D. (2017) The Strange Death of Europe. Immigration, Identity, Islam. London: Bloomsbury.

Nelles, R. (2015) Unapologetic, Unequivocal. The Real Merkel Finally Stands up. Spiegel Online, 16 September 2015. At: http://www.spiegel.de/international/germany/merkel-refuses-toapologize-for-welcoming-refugees-a-1053253.html

Rawls, J. (1971). A Theory of Justice. Cambridge Mass: Harvard University Press.

Nozick, R. (1977). Anarchy, State and Utopia. Oxford: Basil Blackwell.

Sanders, L. (2016) Two million: Germany records largest influx of immigrants in 2015, Deutsche Welle, 21 March. At: http://www.dw.com/en/two-million-germany-records-largest-influx-ofimmigrants-in-2015/a-19131436 (accesses 1 October 2017).

Searle, J. R. (2010). Making the Social World. The Structure of Human Civilization, Oxford: Oxford University Press.

Swift, A. (2006). Political Philosophy. Cambridge: Polity Press.

The Independent (2016) Chilcot Report: read Tony Blair's full statement in response to the Iraq war inquiry', 7 July 2016 (http://www.independent.co.uk/news/uk/politics/chilcot-report-tonyblair-read-response-statement-in-full-iraq-war-inquiry-a7123251.html). 